\title{
Influence of salinity and cadmium on the volume of Pacific herring eggs"
}

\author{
D. F. Alderdice ${ }^{1}$, H. Rosenthal ${ }^{2} \&$ F. P. J. Velsen ${ }^{1}$ \\ ${ }^{1}$ Department of Fisheries and the Environment, Fisheries and Marine Service, \\ Resource Services Branch, Pacific Biological Station; \\ Nanaimo, British Columbia V9R 5K6, Canada, \\ and \\ ${ }^{2}$ Biologische Anstalt Helgoland (Zentrale); \\ Palmaille 9, D-2000 Hamburg 50, Federal Republic of Germany
}

\begin{abstract}
Changes in total volume and volume of the yolk and perivitelline space of Pacific herring eggs were examined throughout incubation at $5^{\circ} \mathrm{C}$ in relation to salinity of the incubation medium $(5,20,35 \% 0 \mathrm{~S})$, and after exposure to cadmium $(0.05-10 \mathrm{ppm} \mathrm{Cd})$ at $20 \%$ S. After fertilization and filling of the perivitelline space there was a decline in total egg volume in all salinities until $60-80 \mathrm{hr}$ after fertilization. There followed a period of relative stability of total volume (100-240 hr), then a slow decline until hatching $(240-619 \mathrm{hr})$. There was an inverse relation between egg volume and salinity at all stages of egg development. Eggs transferred from $20 \%$ to 5 or $35 \% \mathrm{~S}, 87.4 \mathrm{hr}$ after fertilization $(90 \%$ blastodermal overgrowth of the yolk), showed only minor changes in total egg volume within the period of relative stability $(100-240 \mathrm{hr})$. Prior to $80 \mathrm{hr}$, changes in egg volume appeared primarily to be simple adjustments to prevailing osmotic and ionic conditions, modified, however, by presumed irreversible changes induced in the egg in relation to salinity experience at, and shortly after, fertilization. Subsequently, between $80-100 \mathrm{hr}$, egg volume appears to become regulated, commencing in the interval between late blastodermal overgrowth and blastopore closure. Yolk volume declined after fertilization, reached a minimum $40-60 \mathrm{hr}$ after fertilization, increased to $100 \mathrm{hr}$, then decreased in the period of relative stability of total volume - presumably in relation to rapid growth of the embryo. In the latter period, yolk volume appeared resistant to change when eggs are transferred from $20 \%$ to 5 or $35 \%$ S, $87.4 \mathrm{hr}$ after fertilization. Volume of the perivitelline space reached a maximum after fertilization, then decreased until about $100 \mathrm{hr}$; between 100 and $240 \mathrm{hr}$ it increased rapidly and was influenced only in a minor way by salinity changes in the incubation medium $87.4 \mathrm{hr}$ after fertilization. Eggs exposed to cadmium in the interval between $1 / 2$ and $30 \mathrm{hr}$ after fertilization showed major reductions in total egg volume; total volume in the period of relative stability $(100-240 \mathrm{hr})$ was much reduced and normal volume was not recovered after removal of such eggs to uncontaminated water at $30 \mathrm{hr}$.
\end{abstract}

\footnotetext{
* Prepared under the auspices of the Canadian-German Scientific and Technical Cooperation Agreement (Contribution No. 7).
} 


\section{INTRODUCTION}

Pacific herring (Clupea pallasi) eggs are tolerant of a wide range of salinities (Alderdice \& Velsen, 1971), yet a full understanding of the ecological effects of salinity on eggs and larvae of the species has yet to be achieved. A further question of ecological significance has centred on the effects of cadmium as an environmental contaminant (Rosenthal \& Sperling, 1974). During a subsequent cooperative study, the authors had the opportunity to combine their objectives in a study of Pacific herring egg and larval development (Rosenthal \& Alderdice, 1976). A number of aspects of early development were examined, including the effects of salinity and cadmium on bursting pressures of eggs (Alderdice et al., 1979 b). This paper reports observations on total egg volume and volumes of the yolk and perivitelline space during incubation in various salinities and cadmium concentrations.

In general, the diameter and volume of marine teleost eggs of a given species tend to be larger in lower salinities (Holliday, 1965; Kändler \& Tan, 1965; Solemdal, 1967, 1971; Lönning \& Solemdal, 1972; Dushkina, 1973; May, 1974). Less information is available on the influence of cadmium on herring eggs. Rosenthal \& Sperling (1974) and von Westernhagen et al. (1974) incubated Baltic herring (C. harengus) eggs in seawater-cadmium solutions. In neither instance were egg diameters found to be significantly altered by cadmium exposure, although the latter authors found yolk volume of newly hatched larvae to be greater both in higher salinities and higher cadmium concentrations. Egg size in the Baltic flounder, Pleuronectes flesus, does not appear to be influenced by exposure to cadmium during incubation (von Westernhagen \& Dethlefsen, 1975). Yet, Pacific herring egg total volumes were found to be lower in higher salinities and after exposure to cadmium Alderdice et al., 1979 b).

The evidence relating the effects of salinity and cadmium to changes in egg size is far from complete. Cadmium appears to be accumulated to greater levels in eggs possessing thicker jelly coats. Eggs incubating in lower salinities accumulate more cadmium, indicating a potential relation of $\mathrm{Ca}^{++} / \mathrm{Cd}^{++}$ratios to the physical properties of the jelly coat and capsule (von Westernhagen \& Dethlefsen, 1975). Capsule thickness also varies considerably between species $(2-35 \mu \mathrm{m}$ ) (Ginzburg, 1968; Lönning, 1972). Lönning \& Solemdal (1972) demonstrated an inverse relation between specific gravity and egg diameter for eggs of Platichtbys flesus (=Plewronectes flesus) and Limanda limanda from brackish and marine environments; in addition, capsule thickness tended to be greater in eggs from marine waters. Salinity experience of the adult spawner, acting through the osmoconcentration of the ovarian fluid, also may influence the size of the prespawning, ovarian egg (Solemdal, 1967). Hence, the effects of salinity and cadmium on marine eggs during incubation may involve a complex of direct effects and interactions between prespawning and incubation salinities and parameters of the eggs associated with volume and density. 


\section{MATERIALS AND METHODS}

Ripe, adult herring were obtained from a trapnet on Saltspring Island, Georgia Strait, British Columbia, in early March 1974. They were transported to the Pacific Biological Station. Nanaimo, and housed in a circular tank at ambient salinitytemperature conditions. Small numbers of fish were segregated by sex and held in the laboratory for brief periods during preparation of egg samples.

Three experiments were conducted. In two of them, eggs were applied to $1 \%$ Siliclad-treated glass microscope slides in rows of single, separated eggs to facilitate measurement of egg diameter. The slides were stored (Alderdice \& Velsen, 1978 ) in $20 \% \mathrm{~S}$ sea water at $5{ }^{\circ} \mathrm{C}$ for $30-60 \mathrm{~min}$; the eggs then were fertilized simultaneously in $20 \% \mathrm{~S}$ sea water at $5^{\circ} \mathrm{C}$. In the third experiment the eggs were attached to microscope cover slips, fertilized in the manner described, and incubated in open, slotted carrier trays. In each experiment the eggs were left in contact with the herring sperm for $10 \mathrm{~min}$, washed in $20 \% \mathrm{~S}$ sea water at $5{ }^{\circ} \mathrm{C}$, then moved to $40-1$ test tanks for incubation at $5^{\circ} \mathrm{C}$. Further details of the procedures have been described elsewhere (Alderdice et al., $1979 \mathrm{a}, \mathrm{b}$ ).

Measurements of egg volume were made by ocular micrometer in temperaturecontrolled $1 \times 10-\mathrm{cm}$ diameter stage wells. Eggs were ellipsoidal. From the minor $\left(\mathrm{d}_{1}\right)$ and major $\left(\mathrm{d}_{2}\right)$ diameters measured, the computed volume

$$
\mathrm{V}=4 / 3 \pi\left[\left(1 / 2 \mathrm{~d}_{1}\right)^{2}\left(1 / 2 \mathrm{~d}_{2}\right)\right]
$$

From the estimates of egg volume equivalent spherical diameters (d) may be obtained, where $\mathrm{d}=2(2.35619 \mathrm{~V})^{1 / 3}$.

Total volume was obtained for 15-25 eggs at each observation interval. Similar measurements were made for yolk volume. The volume of the perivitelline space was obtained by difference (total-yolk volume). In the first two experiments, total

Table 1

Salinities and cadmium concentrations used in the three experiments. Some egg samples were transferred (trials 4,5 ) from initial conditions to those shown in the table at the following times after fertilization: Expt. 1 - from $20 \% 0 \mathrm{~S}, 10 \mathrm{ppm} \mathrm{Cd}$ to 5 and $35 \% 0 \mathrm{~S}, 0 \mathrm{ppm} \mathrm{Cd}$ at 30-32 hr; Expt. 3 - from 5 to 35 and 35 to $5 \% \mathrm{~S}$, without cadmium, at $87.4 \mathrm{hr}$. All trials were conducted at $5^{\circ} \mathrm{C}$. Some of the results of Expt. 2 have been mentioned elsewhere (Alderdice et al. 1979 b)

\begin{tabular}{|ccccccc|}
\hline $\begin{array}{c}\text { Expt. } \\
\text { No. } \\
\text { trial }\end{array}$ & $\begin{array}{c}\text { Salinity } \\
(\% / 0)\end{array}$ & $\begin{array}{c}\text { Cadmium } \\
(\mathrm{ppm})\end{array}$ & $\begin{array}{c}\text { Salinity } \\
(\% / 00)\end{array}$ & $\begin{array}{c}2 \\
\text { Cadmium } \\
(\mathrm{ppm})\end{array}$ & $\begin{array}{c}\text { Salinity } \\
(\% / 00)\end{array}$ & $\begin{array}{c}3 \\
\text { Cadmium } \\
(\mathrm{ppm})\end{array}$ \\
\hline 1 & 5 & 0 & 5 & 0 & 5 & 0 \\
2 & 20 & 0 & 20 & 0 & 20 & 0 \\
3 & 35 & 0 & 35 & 0 & 35 & 0 \\
4 & $20 \rightarrow 5$ & $10 \rightarrow 0$ & - & - & $5 \rightarrow 35$ & $0 \rightarrow 0$ \\
5 & $20 \rightarrow 35$ & $10 \rightarrow 0$ & - & - & $35 \rightarrow-5$ & $0 \rightarrow 0$ \\
6 & 20 & 0.05 & 20 & 0.05 & - & - \\
7 & 20 & 0.1 & 20 & 0.1 & - & - \\
8 & 20 & 1 & 20 & 1 & - & - \\
9 & 20 & 5 & 20 & 5 & - & - \\
10 & 20 & 10 & 20 & 10 & - & - \\
\hline
\end{tabular}


volumes were obtained approximately at daily intervals from fertilization until hatching. In the third experiment total, yolk and perivitelline space volumes were obtained until $240 \mathrm{hr}$ after fertilization. In estimating the perivitelline space, we recognize that its volume and that of the perivitelline fluid are not equivalent; an increasing proportion of the former was occupied by the developing embryo as incubation proceeded.

Test conditions examined the effects of salinity and cadmium concentration (ppm Cd) on egg volume. Incubation temperatures and salinities were held within $\pm 0.01{ }^{\circ} \mathrm{C}$ and $\pm 0.05 \% \mathrm{~S}$, respectively, of set levels. Cadmium-seawater solutions were prepared from anhydrous $\mathrm{CdCl}_{2}$ and normal sea water $(28 \% 0 \mathrm{~S})$. In all trials, egg samples were inserted into initial test conditions within $30 \mathrm{~min}$ of fertilization. In some of the trials, egg samples were transferred from initial test conditions to other salinity-cadmium levels. The various test conditions and transfer times are shown in Table 1.

\section{RESUITS}

\section{Effects of salinity on egg volume}

Early changes in egg total volume were measured in a preliminary experiment (Fig. 1). Formation of the perivitelline space was detected 7 min following fertilization. Increase in total volume was greatest in $5 \%$, intermediate in $20 \%$, and smallest in $35 \% \mathrm{~S}$. Time to half-maximum volume change was about $1.4 \mathrm{hr}$ at $5 \%, 1.3 \mathrm{hr}$ at $20 \%$ and $0.9-1.0 \mathrm{hr}$ in $35 \% \mathrm{~S}$. Time to maximum volume change

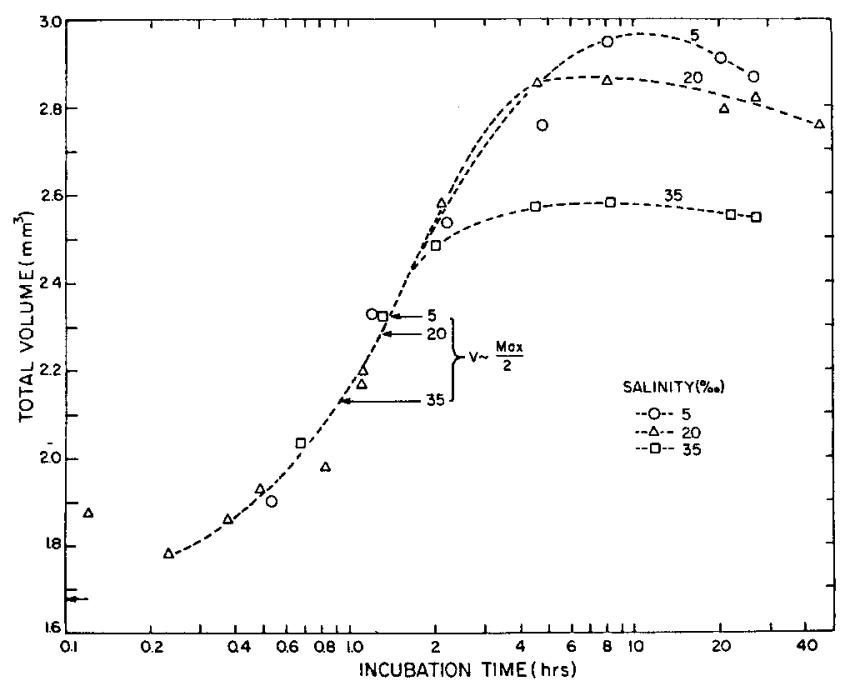

Fig. 1: Total volume of Pacific herring eggs fertilized in $20 \%$ S sea water at $5{ }^{\circ} \mathrm{C}$, including subsamples transferred to 5 and $35 \% \mathrm{~S}$ at $5{ }^{\circ} \mathrm{C}, 10 \mathrm{~min}$ after fertilization 
is estimated as 9-11 hr $(5 \%), 6-9 \mathrm{hr} 20 \%)$, and 6-8 hr $(35 \%$ S). The data indicate that initial volume changes are greater in lower salinities and somewhat more rapid in higher salinities.

In the main experiment mean total volume of eggs fertilized in $20 \% \mathrm{~S}$ at $5{ }^{\circ} \mathrm{C}$, and moved to incubation salinities of 5,20 , and $35 \% \mathrm{~S}$ at $5{ }^{\circ} \mathrm{C}, 30 \mathrm{~min}$ after fertilization, are shown in Fig. 2 (Expt. 1, trials 1-3). Mean total volume of the unfertilized eggs initially was $1.26 \mathrm{~mm}^{3}$ (equivalent spherical diameter, 1.35-1.36 mm). Volume measurements were begun $7 \mathrm{hr}$ after fertilization (Fig. 2); volume changes prior to $7 \mathrm{hr}$ are assumed to approximate those in Fig. 1. Initial increases in total volume, reaching a maximum about $7-10 \mathrm{hr}$ after fertilization (5-35\% S), were followed by a period of volume reduction. In the period from $7 \mathrm{hr}$ onward at $20 \% \mathrm{~S}$ (Fig. 2), total volume declined from $2.19 \mathrm{~mm}^{3}$ (7 hr) to $1.97 \mathrm{~mm}^{3}\left(60 \mathrm{hr}\right.$ ), then rose slightly to stabilize near $2.00 \mathrm{~mm}^{3}$ about $100 \mathrm{hr}$ after fertilization. Following a period of "relative volume stability", occurring from about 100 to $240 \mathrm{hr}$, there began a period of slow volume decrease in which a mean total volume of $1.90 \mathrm{~mm}^{3}$ was reached about $500 \mathrm{hr}$ after fertilization.

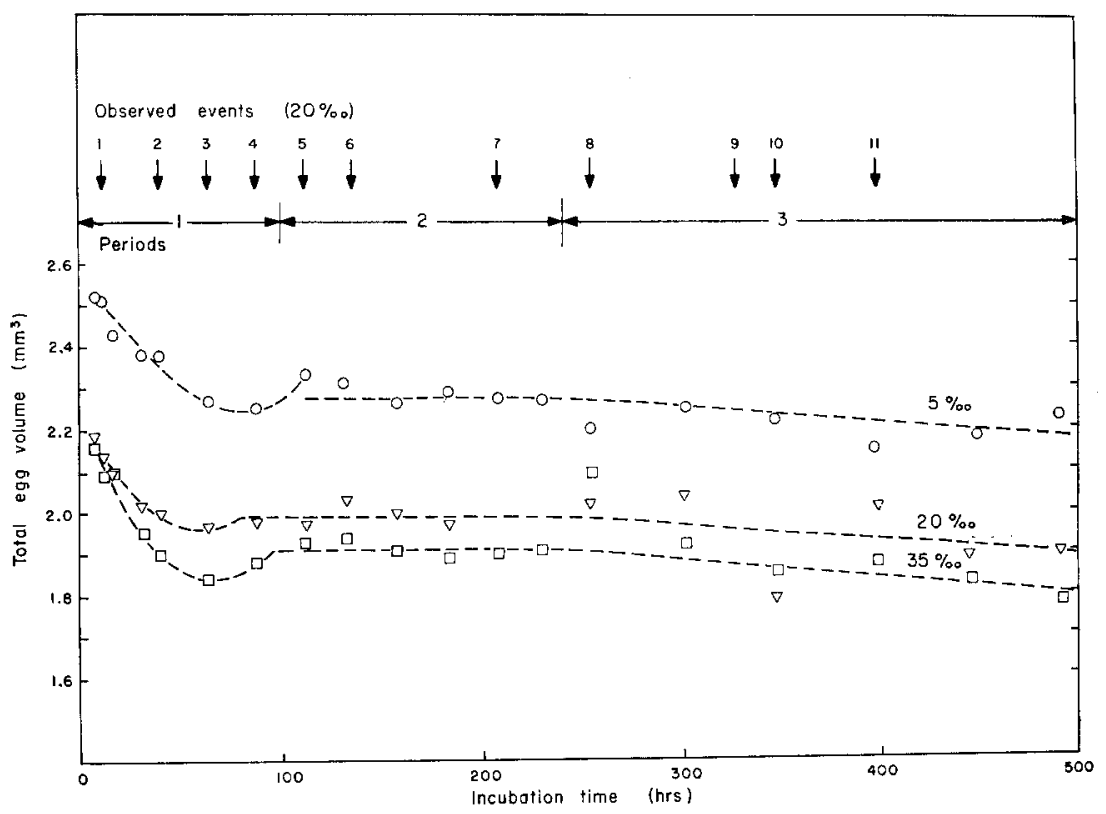

Fig. 2: Total volumes of Pacific herring eggs $\left(\mathrm{mm}^{3}\right)$ fertilized in $20 \% \mathrm{~S}$ at $5{ }^{\circ} \mathrm{C}$ and divided into three groups, which were moved into 5, 20 and $35 \%$ incubation at $5^{\circ} \mathrm{C}$, $30 \mathrm{~min}$ after fertilization. Three periods are indicated: (a) initial volume reduction (first observation at $7 \mathrm{hr}-100 \mathrm{hr}$ ); (b) relative volume stability (100-240 hr); and (c) latter slow decline ( $240 \mathrm{hr}$ to hatching). The observed events at $20 \% \mathrm{~S}$ include 1-8-cell stage; 2 - late blastodisc; 3 -germ ring at equator; 4 -blastoderm $90 \%$ overgrown; 5 -blastopore near closure; 6 -Kupffer's vesicle present, 20 somites; 7 -Kupffer's vesicle prominent, tail bud free; 8-Kupffer's vesicle present, embryo slightly greater than full circle; 9-eye pigmentation beginning; 10 - eyes pigmented; 11 - embryo two full circles, hatching glands prominent. Initial mean volume of unfertilized eggs $-1.26 \mathrm{~mm}^{3}$ 
Coincident with the interval between the end of the period of initial decline in total volume (60-80 hr) and the beginning of the period of relative volume stability $(100 \mathrm{hr})$ were stages of embryonic development beginning with $90 \%$ blastodermal overgrowth, and ending with blastopore closure $(110 \mathrm{hr})$. The transition between the period of relative volume stability and the final decline in total volume (near $240 \mathrm{hr}$ ) occurred between the time the tail bud lifted off the yolk and the time when the embryo had grown to slightly more than encircle the yolk (Fig. 2, events 7,8 ).

The foregoing interpretation allows a comparison to be made between total volumes in the period of relative volume stability at the three incubation salinities. For the first three trials of Expts. 1-3 (Table 1), total egg volumes $\left(\mathrm{mm}^{3}\right.$ ) are as follows (Table 2).

Table 2

Total egg volumes of Experiments 1-3 (see Table 1)

\begin{tabular}{|cccc|}
\hline & \multicolumn{3}{c|}{ Incubation salinity (\%o) } \\
Experiment & 5 & 20 & 35 \\
\hline 1 & 2.28 & 1.99 & 1.91 \\
2 & 1.47 & 1.38 & 1.38 \\
3 & 1.95 & 1.67 & 1.67 \\
\hline Average & 1.90 & 1.68 & 1.65 \\
\hline
\end{tabular}

We suspect that the early changes in total volume, prior to $80 \mathrm{hr}$, are volume adjustments associated primarily with physical and chemical properties of the egg; these could include equilibrium adjustments in the perivitelline fluid, changes in the permeability of the vitelline membrane and perhaps changes in the properties of the capsule and jelly coat. That is, the $\mathrm{t} r \mathrm{e} \mathrm{n}$ of volume adjustment is a property of the egg, while the $\mathrm{level}$ at which the trend occurs is subject to some modification by the salinity of the incubation medium. Between 100 and $240 \mathrm{hr}$, stability of total egg volume suggests that a transition has occurred between volume adjustment and volume $\mathrm{reg} \mathrm{ula}$ tion. This transition is coincident with late blastodermal overgrowth of the yolk, supporting the related observation of Holliday \& Jones (1965) that the onset of osmotic regulation is associated with development of the blastoderm and is complete after blastopore closure.

A further comparison is made between the five trials of Expt. 3 (Table 1) in which some of the eggs (trials 4,5 ) were subject to salinity change $87.4 \mathrm{hr}$ after

Fig. 3: (a) Total volume, (b) yolk volume, and (c) volume of the perivitelline space of Pacific herring eggs $\left(\mathrm{mm}^{3}\right)$, fertilized in $20 \% 0 \mathrm{~S}$ at $5{ }^{\circ} \mathrm{C}$, divided into three groups and moved 12-14 min after fertilization into incubation salinities of 5,20 and $35 \%$ at $5{ }^{\circ} \mathrm{C}$. At the time of transfer ( $\mathrm{T}-87.4 \mathrm{hr}$ ), one-half the eggs at $5 \% \mathrm{~S}$ were moved to $35 \%$, and one-half those at $35 \%$ were moved to $5 \% 0 \mathrm{~S}$. The eggs at $20 \% \mathrm{~S}$ were not transferred. Transfers were made at the time of $90 \%$ blastodermal overgrowth. The trends are plotted on the basis of those in Fig. 1. Panels: (a) total volume, (b) yolk volume, (c) volume of the perivitelline space. The bars $(5 \%$ ) represent standard errors of the means. 

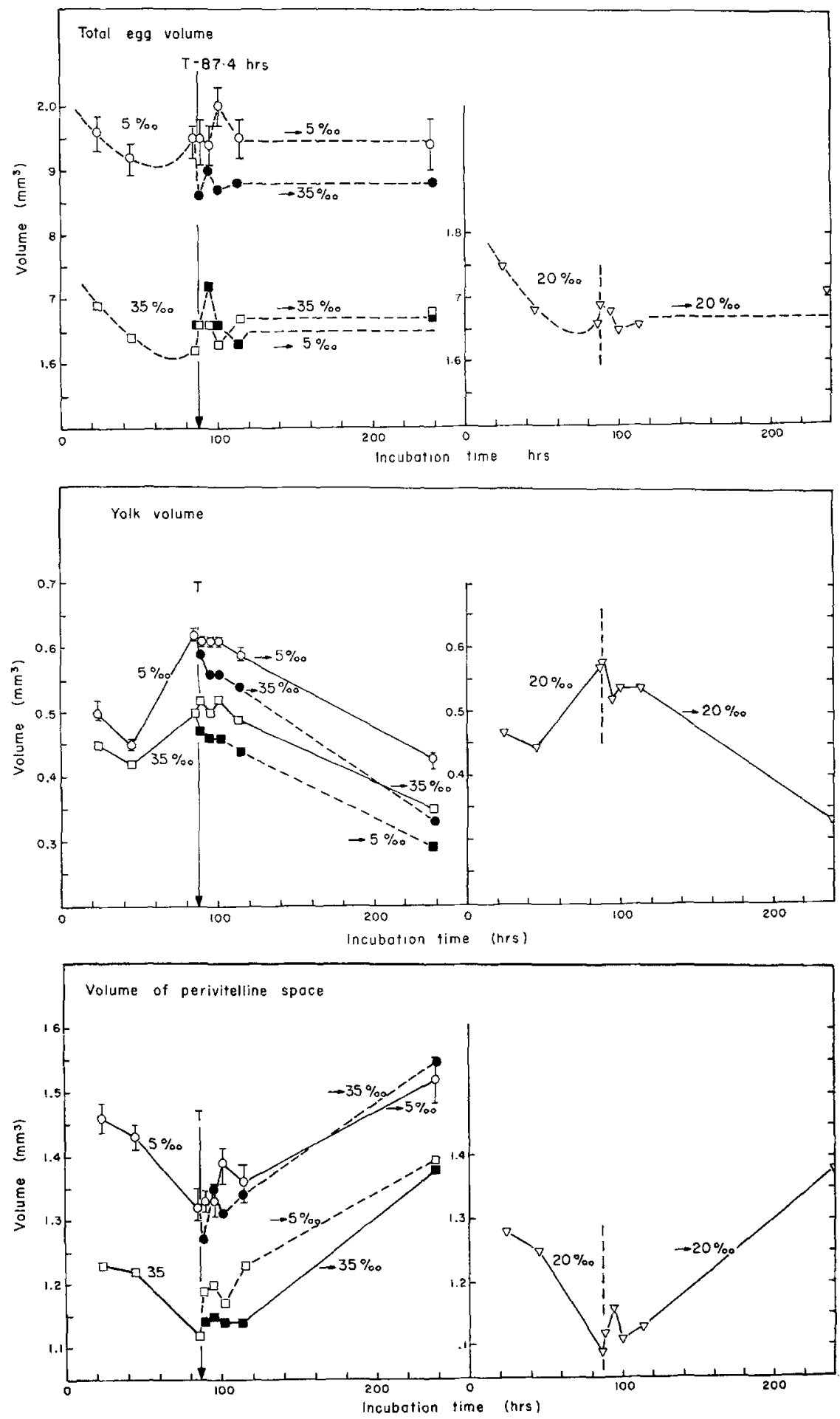
fertilization. Changes in total volume were small following this transfer (Fig. 3a), and the eggs did not assume those volumes attained in the eggs that were not transferred (trials 1,3). If the proposition is accepted that volume and osmotic regulation are established between 80 and $100 \mathrm{hr}$, then the total volumes of the eggs subjected to salinity transfer represent either the effect of volume regulation, the trend in volume adjustment set by early salinity experience (prior to $80 \mathrm{hr}$ ), or both. The latter is suspected. That is, as before, the trend of early volume adjustment is a property of the egg, the level at which the trend occurs is subject to some modification by subsequent salinity change, and after $80 \mathrm{hr}$ the amount of modification is controlled by tissue regulation.

In general in the period prior to salinity transfer, yolk volumes (Fig. 3b) followed the trends of change shown for total volume. Subsequently, eggs in all salinities showed a decline in yolk volume in the period in which total volumes were relatively stable (100-240 hr). In the eggs transferred from 5 to $35 \% \mathrm{~S}$, yolk volume ultimately assumed a value approximating that for eggs remaining in $35 \% \mathrm{~S}$. However, as for total volume, yolk volume in eggs transferred from 35 to $5 \% \mathrm{~S}$ remained substantially lower than that of the eggs remaining in $5 \% \mathrm{~S}$ at $87.4 \mathrm{hr}$. Undoubtedly, the general decline in yolk volume of eggs in all salinities reflects the metabolism of yolk by the growing embryo. The changes in yolk volume associated with salinity transfer are assumed mainly to reflect the movement of water across the membrane surrounding the yolk. If this is the case then the exchange rates for ingress and egress of yolk water would differ. Eggs transferred from low to high salinities appear to lose water more readily than eggs transferred from high to low salinities.

Volume of the perivitelline space (Fig. 3c) was obtained as the difference between total volume and yolk volume. Volume of the perivitelline space appears to decline and reach a minimum at the time of the assumed onset of regulation of total volume and osmoconcentration of the egg $(80-100 \mathrm{hr})$. Thereafter $(100-240 \mathrm{hr})$ there is an increase in the volume of the perivitelline space - which increasingly would be occupied by the developing embryo. Following the transfer of eggs to other salinities $(87.4 \mathrm{hr})$, the volume of the perivitelline space in those transferred from a lower to a higher salinity does not vary appreciably in comparison with those remaining in the lower $(5 \%$ ) salinity. Conversely, for the eggs transferred from a higher to a lower salinity, there is a transient increase in volume of the perivitelline space; however, by the end of the period $(100-240 \mathrm{hr})$ this difference is virtually eliminated.

Taking the three compartments of egg volume into consideration (Fig. 3a, b, c), there appears to be a parallel decrease in volume of the total egg, the yolk, and the perivitelline space beginning approximately $20 \mathrm{hr}$ after fertilization. About $60-80 \mathrm{hr}$ after fertilization total volume reaches a minimum then increases slightly to achieve a stable value by $80-100 \mathrm{hr}$. Coincidentally, there is an increase in yolk volume to a maximum near $100 \mathrm{hr}$ and a related decline in the volume of the perivitelline space. In the following interval (100-240 hr) total volume is relatively constant and a coincident decline in yolk volume is compensated by an increase in volume of the perivitelline space. Events following salinity transfer $(87.4 \mathrm{hr})$ suggest that exchange 
of water between the yolk and its surroundings is more rapid for yolk water loss following transfer to a higher salinity than for water uptake following transfer to a reduced salinity. Furthermore, the volumes of the three compartments generally are more comparable for eggs in 20 or $35 \% \mathrm{~S}$, compared with those at $5 \% \mathrm{~S}$, suggesting that volume regulation may be more efficient at salinities near and above $20 \%$.

\section{Influence of cadmium on egg volume}

The trends of change in total volume of eggs transferred to cadmium solutions $(20 \%$ S) within 30 min after fertilization Table 1, Expts. 1, 2; trials 6-10) were identical with those shown in Fig. 2. Howeyer, total egg volume tended to be lower in relation to increasing cadmium concentration (Table 3 ).

\section{Table 3}

Mean total volume $\left(\mathrm{mm}^{3}\right)$ of herring eggs fertilized in $20 \% \mathrm{~S}$ at $5^{\circ} \mathrm{C}$ and moved within 30 min into various cadmium concentrations $\left(20 \% \mathrm{~S}, 5{ }^{\circ} \mathrm{C}\right)$ for incubation. Egg volumes are averages of eggs measured in the period of relative volume stability of the whole egg $(100-240 \mathrm{hr})$. Eggs in the two experiments (Expts 1,2; trials 6-10) were of different initial sizes; relative volumes are shown in relation to volumes of the controls (Expt. 1, 2; trial 2) (for experiments and trials, see Table 1)

\begin{tabular}{|cccccc|}
\hline $\begin{array}{c}\text { Experiment } \\
\text { cadmium } \\
(\mathrm{ppm})\end{array}$ & $\begin{array}{c}\text { Volume } \\
\left(\mathrm{mm}^{3}\right)\end{array}$ & $\begin{array}{c}\text { Relative } \\
\text { volume }\end{array}$ & $\begin{array}{c}\text { Volume } \\
\left(\mathrm{mm}^{3}\right)\end{array}$ & $\begin{array}{c}2 \\
\text { Relative } \\
\text { volume }\end{array}$ & $\begin{array}{c}\text { Relative } \\
\text { volume (av.) }\end{array}$ \\
\hline 0 (controls) & 2.00 & 1.00 & 1.38 & 1.00 & 1.00 \\
.05 & 2.08 & 1.04 & 1.39 & 1.03 & 1.04 \\
.1 & 1.91 & 0.96 & 1.33 & 0.96 & 0.96 \\
1 & 1.95 & 0.98 & 1.20 & 0.86 & 0.92 \\
5 & 1.67 & 0.84 & 1.30 & 0.94 & 0.89 \\
10 & 1.61 & 0.81 & 1.17 & 0.84 & 0.83 \\
\hline
\end{tabular}

A further series of trials (Table 1, Expt. 1, trials 4, 5) examined to effects of early exposure of eggs to cadmium, followed by a salinity change. These eggs were fertilized in $20 \% \mathrm{~S}$ at $5^{\circ} \mathrm{C}$ and moved to $10 \mathrm{ppm} \mathrm{Cd}\left(20 \% \mathrm{~S}, 5{ }^{\circ} \mathrm{C}\right), 30 \mathrm{~min}$ after fertilization. Subsequently the eggs were divided into three lots; $30 \mathrm{hr}$ after fertilization the lots were transferred to cadmium-free water of 5,20 and $35 \% \mathrm{~S}$ at $5^{\circ} \mathrm{C}$, and incubation was continued (Fig. 4). In the figure, comparison of the cadmium-exposed eggs with those of the controls (Expt. 1, trial 2) shows a substantial decrease in total egg volume occurring in relation to cadmium exposure. Although the trends are similar in the cadmium-exposed and the control eggs, the levels of the former are much below the latter. Obviously these differences in total volume were initiated in the period of cadmium exposure prior to salinity transfer. The levels of total volume established prior to salinity transfer at $30 \mathrm{hr}$ appear to be fixed by events during the first $30 \mathrm{hr}$ of exposure to cadmium. 


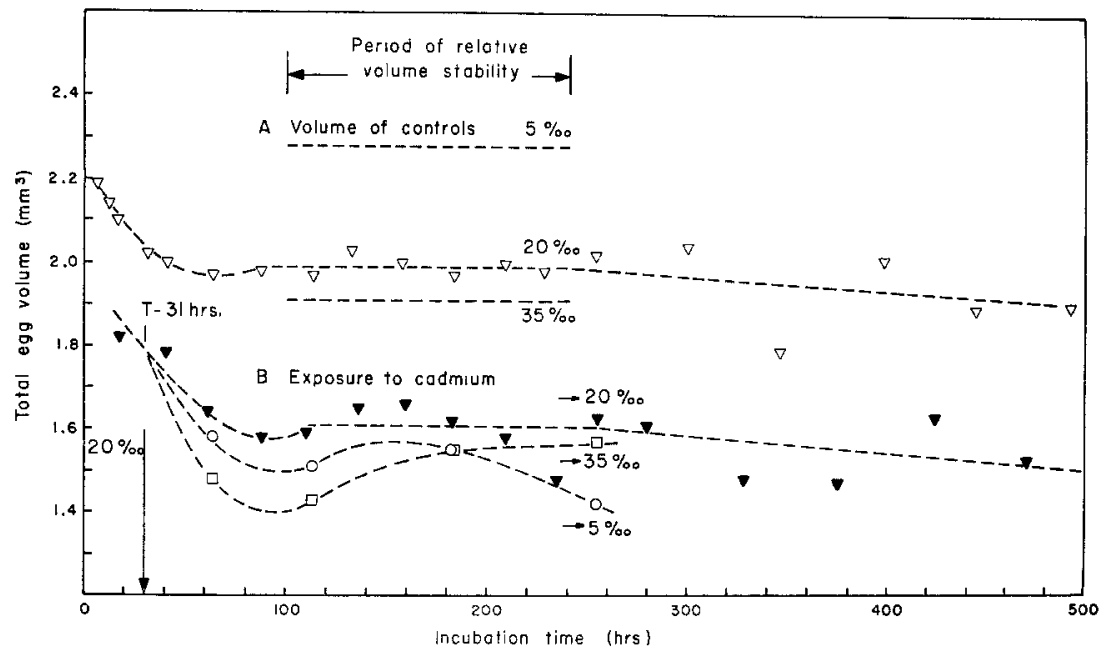

Fig. 4: Trends of change in total volume of Pacific herring eggs. (A) fertilized in 20\% $\mathrm{S}$ at $5{ }^{\circ} \mathrm{C}$ and transferred to 5,20 , or $35 \%$ So cadmium) $30 \mathrm{~min}$ later (Fig. 1); (B) fertilized in $20 \% \mathrm{~S}$ at $5{ }^{\circ} \mathrm{C}$, moved to $10 \mathrm{ppm}$ cadmium in $20 \% \mathrm{~S}$ at $5{ }^{\circ} \mathrm{C}, 30 \mathrm{~min}$ after fertilization, then transferred to cadmium-free water $(5,20,35 \% \mathrm{~s})$ at $30 \mathrm{hr}$. The $30-\mathrm{hr}$ initial cadmium exposure results in a reduction in total volume that persists when the eggs were transferred to cadmium-free water

\section{DISCUSSION}

Much work has been done in examining the related properties of egg size, internal pressure, vitelline membrane and capsule permeability, and ionic and osmotic relations for eggs of various teleost species. Nevertheless, the interrelations between these characteristics generally are obscure and remain largely speculative, particularly in ecological situations involving the related considerations of egg density and buoyancy. In the current instance it seems advisable to review some of the known facts as a framework for viewing the information on egg volume.

Epel (1977) recently reviewed the processes initiated within the first 10-20 min following fertilization of the sea urchin (Strongylocentrotus sp.) egg. It is assumed that the ground plan is similar to that in the teleost egg, even though some of the structures may differ. Following sperm entry and fusion there is a small influx of sodium ions and a transient internal release of calcium ions into the cytoplasm. The calcium ions appear to change the permeability of the plasma membrane. The cortical alveoli rupture, and their contents (Eddy, 1974; Epel, 1977) occupy the presumptive perivitelline space where the colloid osmotic pressure results in imbibition of water from the external environment. Coincident with the start of the cortical reaction is an increased influx of sodium ions into the cytoplasm, a parallel efflux of protons and increased alkalinity of the cytoplasm, which appears to commit the egg to begin biosynthesis and embryonic development.

In the teleost egg the plasma membrane surrounding the yolk is highly permeable initially; after fertilization its permeability decreases, reaching minimum 
levels within $24 \mathrm{hr}$ or by the end of water hardening (Loeffler, 1971; Potts \& Eddy, 1973). During this early period other changes are occurring, including a reduction in yolk volume, formation of the perivitelline fluid, and changes in the outer capsule. Presumably decrease in yolk volume is a result largely of water loss during the period of high permeability of the plasma membrane. In the herring this appears to continue until a minimum is reached about $40-60 \mathrm{hr}$ after fertilization (Fig. 3b). The fact that the bulk of the egg comprises the yolk prior to fertilization forces this conclusion, as the yolk would be incompressible and its volume was reduced from about 1.26 to $0.45 \mathrm{~mm}^{3}$ (Fig. 3b) during the first $40 \mathrm{hr}$. In many teleost eggs, formation of the perivitelline fluid is attended by a concurrent expansion of the outer capsule under the increasing internal turgor pressure (Kao et al., 1954; Prescott, 1955; Solemdal, 1967, 1971; Holliday, 1969; Potts \& Eddy, 1973; Eddy, 1974). In some eggs, swelling of the total egg may not occur (Kao \& Chambers, 1954; Kao, 1956), volume changes being limited largely to the yolk. The increasing internal turgor pressure of the Pacific herring egg appears to reach a maximum in the first 10 to $40 \mathrm{hr}$ after fertilization at salinities of 35 and $20 \%$ (Alderdice et al., 1979 b). At equilibrium, the internal pressure within the capsule, established by the osmotic and ionic gradients between the perivitelline fluid and the incubation medium, will be balanced by the circumferential tension exerted by the elastic forces of the capsule (Eddy, 1974). The total volume achieved by the egg will be a function of the internal pressure, the circumferential tension, and the diameter of the egg (Burton, 1962). The tension itself presumably is related to capsule thickness, and this can vary for a given species according to the salinity experience of the adults from which the eggs were obtained (Lönning \& Solemdal, 1972). Other, somewhat more protracted changes occur in the capsule and, where present, in its enveloping jelly coat. "Hardening" of the salmonid egg capsule is complete about 3 days after fertilization (Zotin, 1958) in a process that appears to involve some alteration in capsule structure. The jelly coat of Pacific herring eggs loses bound water after being shed; it thins and becomes harder in relation to the salinity of the incubation medium. It appears to contribute to the strength of the capsule (Rubtsov, 1973). Capsule strength of the Pacific herring egg in $20 \% \mathrm{~S}$ at $5{ }^{\circ} \mathrm{C}$ reaches a maximum about $40 \mathrm{hr}$ after fertilization (Alderdice et al., $1979 \mathrm{~b}$ ).

Summarizing these observations in relation to the Pacific herring egg, it appears that a number of interrelated events contribute to volume adjustment of the egg soon after fertilization. These result in attainment of an apparent state of dynamic equilibrium within the first $40-80 \mathrm{hr}$, prior to blastodermal overgrowth and initiation of tissue regulation assumed to start between 80 and $100 \mathrm{hr}$. These events include formation of the perivitelline fluid and swelling of the whole egg to maximum volume, a decrease in yolk volume and subsequent reduction in total volume - both reaching minimum values about $40-80 \mathrm{hr}$ after fertilization. These changes undoubtedly are influenced by the osmotic and ionic gradients between the perivitelline fluid and the external medium, by changes in permeability of the plasma membrane, by the internal pressure in relation to tension in the capsule, and by changes that may occur in the structure of the capsule and jelly coat that would modify their elastic properties. 
About $80-100$ hr after fertilization a new set of events occurs, signified by an increase in yolk volume (Fig. $3 \mathrm{~b}$ ) and volume of the perivitelline space (Fig. 3c). The corresponding change occurring in total volume is transient and minor (Fig. 3a). As mentioned earlier, this stage of development - between $90 \%$ blastodermal overgrowth and blastopore closure - coincides with the period in which osmoregulation of the yolk begins in C. harengus (Holliday \& Jones, 1965; Holliday, 1969). On the basis of further available data on osmoconcentration, to be reported elsewhere, we concur with these earlier observations. We conclude that the events prior to $80-100 \mathrm{hr}$ are aspects of passive adjustment, those following signifying the beginning of active osmoregulation.

Between 100 and 200-250 hr total egg volume is relatively constant (Fig. 2), while yolk volume begins to diminish rapidly (Fig. 3b). The latter undoubtedly is a result of yolk utilization by the rapidly developing embryo. In the same period the volume of the perivitelline space increases.

From approximately $240-250 \mathrm{hr}$ onward the total volume of the egg begins to decline slowly. This decline is associated with a slow, steady increase in osmolality of the perivitelline fluid, but not the yolk, in salinities below $35 \%$ (Alderdice et al., 1979 a). The observation suggests that water is lost progressively from the perivitelline fluid, or that metabolites may be accumulating in the perivitelline fluid during later stages of embryonic development. The decline in total egg volume, starting after 240-250 hr, does not appear to be associated with hatching enzyme activity. Decreasing bursting pressure of a companion set of eggs (Alderdice et al., $1979 \mathrm{~b}$ ), associated with the onset of hatching, did not begin until about $500-550 \mathrm{hr}$ after fertilization and hatching began at $619 \mathrm{hr}$.

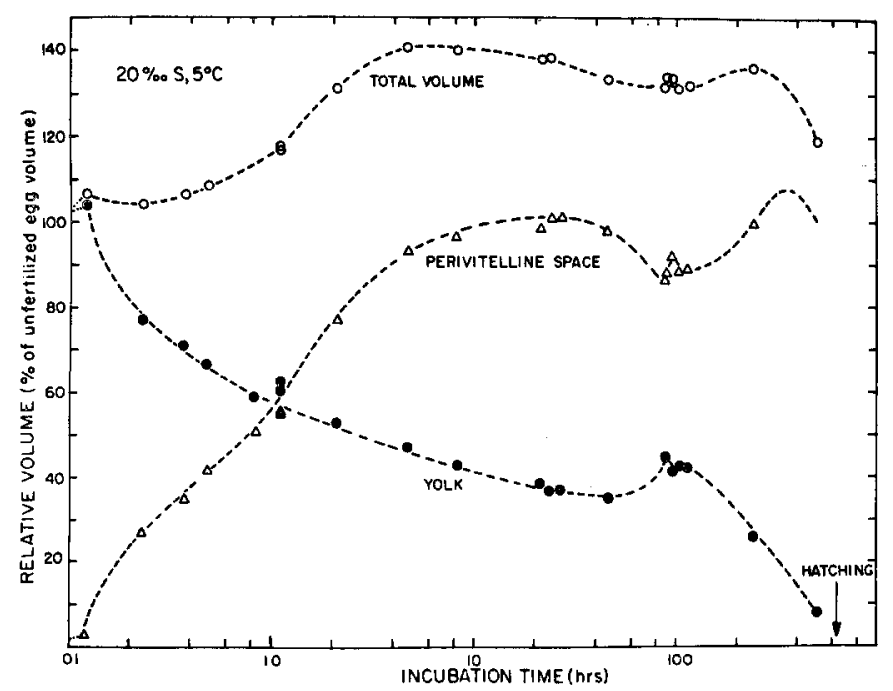

Fig. 5: Trends of change in total volume, yolk volume, and perivitelline space volume based largely on the data of Fig. 1 and 2, and other incidental observations near hatching, for Pacific herring eggs fertilized and incubated in $20 \% \mathrm{~S}$ at $5{ }^{\circ} \mathrm{C}$ (no cadmium, no salinity transfer). All volumes are relative to the mean dimensions of the unfertilized eggs at zero time (total volume, $1.26 \mathrm{~mm}^{3}$ ) 
Although the timing of all the aforementioned events is not well defined, some appreciation of the apparent trends in total volume, yolk and perivitelline space volume can be obtained from the available data. These trends, based largely on the data in Figs. 1-3, are shown in Fig. 5. Associated with the relative decline in volume of the perivitelline space after about $350 \mathrm{hr}$ (Fig. 5) was an increase in viscosity of the perivitelline fluid. This was most apparent after $600 \mathrm{hr}$.

\section{Effects of cadmium on egg volume}

Evidence indicates that calcium is involved in normal "hardening" of the teleost egg (Nakano, 1969). More cadmium is bound to eggs in dilute sea water (von Westernhagen et al., 1975), and the inference is drawn that cadmium competes with calcium for binding sites during the process of water hardening. We conclude that $\mathrm{Ca}^{++} / \mathrm{Cd}^{++}$ratios would influence the amount of cadmium bound to the egg and that this binding probably interferes with structural changes in the outer covering of the egg during water hardening (Alderdice et al., 1979 b). Further evidence of such changes arises in the fact that exposure to cadmium produces fragile eggs, susceptile to rupture, in Baltic herring (von Westernhagen et al., 1974; Rosenthal \& Sperling, 1974), in the Baltic flounder (von Westernhagen \& Dethlefsen, 1975) and in the Pacific herring (Alderdice et al., 1979 b).

Rosenthal \& Sperling (1974) exposed Baltic herring eggs to cadmium and noted its distribution in eggs just prior to hatching. For eggs incubated in $5 \mathrm{ppm} \mathrm{Cd}$ they found $70 \%$ of the cadmium content in the outer covering ("chorion") of the eggs, $24 \%$ in the embryo and the remainder in the yolk. They concluded that cadmium forms complexes with components of the capsule, changing its physico-chemical properties. We suspect, as do von Westernhagen \& Dethlefsen (1975), that considerable binding of cadmium occurs in the mucopolysaccharide of the jelly coat. The contribution of the jelly coat to the strength of the outer covering of the egg (Rubtsov, 1973) could be altered by cadmium exposure. Yet capsule fragility and changes in tensile strength of the outer covering in cadmium-exposed eggs (Alderdice et al., 1979) suggest that the elastic properties of the capsule itself also are involved.

Comparing cadmium uptake in eggs of the Baltic herring and Baltic flounder, it is noted that both capsule and jelly coat are thicker in the former. Capsule thickness in the herring egg is reported as about $16 \mu \mathrm{m}$ (von Westernhagen et al., 1975) to $32.5 \mu \mathrm{m}$ (Ginzburg, 1968); in the flounder it is 1.1-2.5 $\mu \mathrm{m}$ (Lönning 8 Solemdal, 1972; Lönning, 1972). The jelly coat of the demersal Baltic and Pacific herring egg is substantial and is noted for its adhesive properties. We have no direct evidence concerning the presence or thickness of a jelly coat in the Baltic flounder egg. The egg is non-adhesive; if a jelly coat is present it must be very thin. If cadmium uptake is proportional to the thickness (or volume) of the jelly coat and capsule, then more bound cadmium would be expected in the herring egg. This assumption is supported by the results of von Westernhagen et al. (1975), which show that in $16 \% \mathrm{~S}$ sea water Baltic herring eggs accumulate, proportionally, 7-14 times as much cadmium as do eggs of the Baltic flounder. In addition, a com- 
parison of the eggs of three species exposed to cadmium (von Westernhagen et al., 1975) showed the amount of cadmium accumulated was related neither to surface area nor egg volume. In general, the evidence indicates that cadmium ist accumulated at higher concentrations in the outer covering of eggs possessing thicker jelly coats and in lower salinities. It remains unclear how bound cadmium is distributed in the outer covering of the egg. We suspect that cadmium must be bound both in the capsule and jelly coat as both layers appear to be affected by exposure to cadmium.

It also appears that cadmium is rather strongly bound to the outer covering of the Pacific herring egg. In the current experiments, transfer of eggs to uncontaminated water $30 \mathrm{hr}$ after fertilization did not result in recovery of normal egg volume in the following $470 \mathrm{hr}$ of incubation (Fig. 4, 20\% S). Alternatively, structural changes in the capsule associated with water hardening probably are complete within the first $30 \mathrm{hr}$. It could be assumed these changes are irreversible and subject to modification so that egg size is reduced in the presence of cadmium. Under those circumstances the irreversible alteration of capsule structure might define the subsequent response of the egg to salinity, even though the eggs were removed to an uncontaminated environment.

In the foregoing, many questions and assumptions have been raised. We suggest that a resolution of many of them could be possible in a simultaneous examination of the relations between internal (turgor) pressure, egg size, capsule wall tension, bursting pressure, capsule thickness, osmotic properties of the egg, and examination of the properties of the jelly coat.

From an ecological viewpoint, the weakened capsule of eggs exposed to cadmium could result in increased mechanical damage from wave action or turbulence, affecting either pelagic or demersal eggs (see Pommeranz, 1974). In addition, the reduction in egg volume noted in this study, resulting from exposure to cadmium, could alter buoyancy relations in pelagic eggs, altering their normal location in the water column in relation to environmental salinity.

\section{ZUSAMMENFASSUNG}

Unter dem Einfluß verschiedener Salzgehalte und Cadmium-Konzentrationen wurden im Verlauf der Inkubationszeit die Volumenänderungen der Eier, des Dotters und des perivitellinen Raumes untersucht. Unmittelbar nach der Befruchtung beginnt die Bildung des perivitellinen Raumes, die bei $5{ }^{\circ} \mathrm{C}$ nach etwa 6 bis $11 \mathrm{~h}$ abgeschlossen ist. Dieser Vorgang erfolgt in hohen Salzgehalten schneller. Nach der anfänglichen Wasseraufnahme verringert sich das Eivolumen im Verlauf von 60 bis 80 h der Inkubationszeit leicht, bleibt jedoch im Zeitraum zwischen 100 und 240 h nach der Befruchtung weitgehend stabil, um danach weiter geringfügig abzunehmen. Die Periode relativ stabiler Volumina fällt mit dem Einsetzen der Osmoregulation der Eier zusammen. Das Dottervolumen erreicht etwa 40-60 h nach der Befruchtung ein erstes Minimum, schwillt dann bis zu einem Embryoalter von etwa 100 h voribergehend leicht an, um dann bis zum Schlupfzeitpunkt kontinuierlich abzunehmen. Der perivitelline Raum verändert nach der anfänglichen Wasseraufnahme sein Volumen ständig. Ein erstes Maximum 
wird nach 20-30 h Inkubationszeit erreicht. Das zweite Volumen-Maximum tritt nach etwa $350 \mathrm{~h}$ Entwicklungsdauer auf. Eine Überführung der Eier in verschiedene Salzgehalte im Embryoalter von etwa $87 \mathrm{~h}$ ergab keine nennenswerten Volumensänderungen. Es wird daraus geschlossen, daß das Eivolumen während der Bildung des perivitellinen Raumes weitgehend festgelegt wird. Eine Exposition der Eier gegenüber Cd während der ersten $30 \mathrm{~h}$ der Inkubationszeit hatte in Abhängigkeit von der Konzentration eine erhebliche Volumenminderung zur Folge. Diese Reduktion der Eigröße war irreversibel.

Acknowledgements. The authors acknowledge and appreciate the assistance of their colleagues in the foregoing study, including Drs. T. R. Rao, H. von Westernhagen, and Ms. M. Bell.

\section{LITERATURE CITED}

Alderdice, D. F. \& Velsen, F. P. J., 1971. Some effects of salinity and temperature on early development of Pacific herring (Clupea pallasi). J. Fish. Res. Bd Can. 28, 1545-1462.

- - 1978. Effects of short-term storage of gametes on fertilization of Pacific herring eggs. Helgoländer wiss. Meeresunters. 31, 485-498.

- Rao, T. R. \& Rosenthal, H., 1979 a. Osmotic responses of eggs and larval of the Pacific herring to salinity and cadmium. Helgoländer wiss. Meeresunters.

- Rosenthal, H. \& Velsen, F. P. J., 1979 b. Influence of salinity and cadmium on capsule strength in Pacific herring eggs. Helgoländer wiss. Meeresunters. 32, 149-162.

Burton, A. C., 1962. Physical principles of circulatory phenomena: the physical equilibria of the heart and blood vessels. In: Handbook of physiology. Section 2: Circulation. Ed. by W. F. Hamilton \& P. Dow. Am. Physiol. Soc., Washington, D.C., 1, 85-106.

Dushkina, L. A., 1973. Influence of salinity on eggs, sperm and larvae of low-vertebral herring reproducing in the coastal waters of the Soviet Union. Mar. Biol. 19, 210-223.

Eddy, F. B., 1974. Osmotic properties of the perivitelline fluid and some properties of the chorion of Atlantic salmon eggs (Salmo salar). J. Zool. 174, 237-243.

Epel, D., 1977. The program of fertilization. Scient. Am. 237, 128-138.

Ginzburg, A. S., 1972. Fertilization in fishes and the problem of polyspermy. Israel Program for Scientific Translations, Jerusalem, $366 \mathrm{pp}$.

Holliday, F. G. T., 1965. Osmoregulation in marine teleost eggs and larvae. Calif. Coop. oceanic Fish. Invest. 10, 89-95.

- 1969. The effcets of salinity on the eggs and larvae of teleost. In: Fish physiology. Ed. by W. S. Hoar \& D. J. Randall. Acad. Press, New York 1, 293-311.

- \& Jones, M. P., 1965. Osmotic regulation in the embryo of the herring (Clupea barengus). J. mar. biol. Ass. U.K. 45, 305-311.

Kändler, R., \& Tan, E. O., 1965. Investigations of the osmoregulation in pelagic eggs of gadoid and flatfishes in the Baltic. I. Changes in volume and specific gravity at different salinities. C. M. - I. C. E. S, D 43.

Kao, C.-Y., 1956. Pressure-volume relationships of the Fundulus egg in sea water and in Sucrose. J. gen. Physiol. 40, 91-105.

- \& Chambers, R., 1954. Internal hydrostatic pressure of the Fundulus egg. I. The activated egg. J. exp. Biol. 31, 139-149.

- Chambers, R. \& Chambers, E. L., 1954. Internal hydrostatic pressure of the Fundulus egg. II. Permeability of the chorion. J. cell. comp. Physiol. 44, 447-461.

Loeffler, C. A., 1971. Water exchange in the pike egg. J. exp. Biol. 55, 797-811.

Lönning, S., 1972. Comparative electron microscopic studies of teleostean eggs with special reference to the chorion. Sarsia $49,41-48$. 
- \& Solemdal, P., 1972. The relation between thickness of chorion and specific gravity of eggs from Norwegian and Baltic flatfish populations. FiskDir. Skr. (Ser. Havunders) 16, 77-88.

May, R. C., 1974. Factors affecting buoyancy in the eggs of Bairdiella icistica (Pisces: Sciaenidae). Mar. Biol. 28, 55-59.

Nakano, E., 1969. Fertilization. In: Comparative morphology, biochemistry, and immunology. Ed. by C. B. Metz \& A. Monroy. Acad. Press, New York, 2, 295-324.

Pommeranz, T., 1974. Resistance of plaice eggs to mechanical stress and light. In: The early life history of fish. Ed. by J. H. S. Blaxter. Springer, Berlin, 397-416.

Potts, W. T. W. \& Eddy, F. B., 1973. The permeability to water of the eggs of certain marine teleosts. J. comp. Physiol. 82, 305-315.

Prescott, D. M., 1955. Effect of activation on the water permeability of salmon eggs. J. cell. comp. Physiol. 45, 1-12.

Rosenthal, H. \& Alderdice, D. F., 1976. Sublethal effects of environmental stressors, natural and pollutional, on marine fish eggs and larvae. J. Fish. Res. Bd Can. 33, 2047-2065.

- \& Sperling, K.-R., 1974. Effects of cadmium on development and survival of herring eggs. In: The early life history of fish. Ed. by J. H. S. Blaxter. Springer, Berlin, 383-396.

Rubtsov, V. V., 1973. The strength of the egg membranes and the volume of adhesive and nonadhesive eggs of wild carp and cultured carp (Cyprinus carpio L.) under different methods of incubation. J. Ichthyol. 13, 400-405.

Solemdal, P., 1967. The effect of salinity on buoyancy, size and development of flounder eggs. Sarsia 29, 431-442.

- 1971. Prespawning flounders transferred to different salinities and the effects on their eggs. Vie Milieu (Suppl.) 22, 409-423.

Westernhagen, H. von \& Dethlefsen, V., 1975. Combined effects of cadmium and salinity on development and survival of flounder eggs. J. mar. biol. Ass. U.K. 55, 945-957.

- - Rosenthal, H., 1975. Combined effects of cadmium and salinity on development and survival of garpike eggs. Helgoländer wiss. Meeresunters. 27, 268-282.

- Rosenthal, H., \& Sperling, K.-R., 1974. Combined effects of cadmium and salinity on development and survival of herring eggs. Helgoländer wiss. Meeresunters. 26, 416-433.

Zotin, A. I., 1958. The membrane hardening enzyme of salmon eggs. Dokl. Akad. Nauk SSSR 121, 1105-1108. 